\title{
Diagnostic value of serum pentraxin 3 level in children with acute appendicitis
}

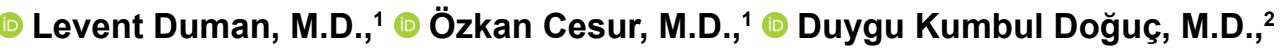

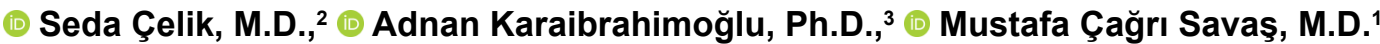

\author{
${ }^{1}$ Department of Pediatric Surgery, Süleyman Demirel University Faculty of Medicine, Isparta-Turkey \\ 2Department of Biochemistry, Süleyman Demirel University Faculty of Medicine, Isparta-Turkey \\ ${ }^{3}$ Department of Biostatistics and Medical Informatics, Süleyman Demirel University Faculty of Medicine, Isparta-Turkey
}

\begin{abstract}
BACKGROUND: Appendicitis is one of the most common surgical emergencies. Early diagnosis of appendicitis is important in children because any delay in treatment substantially leads to complicated appendicitis. In this study, we aimed to test the diagnostic value of pentraxin 3 (PTX3) level in children with acute appendicitis and to investigate whether there is a relationship between the progression of the disease and PTX3 level.

METHODS: This prospective study included 70 children. They were divided into three groups as follows: group I (appendicitis; $n=37$ ), group 2 (abdominal pain; $n=25$ ), group 3 (control; $n=8$ ). Demographic data, medical history, the time from the onset of symptoms to blood sampling, operative and pathological findings of the patients were noted, and white blood cell (WBC), C-reactive protein (CRP) and PTX3 values were measured.

RESULTS: The mean WBC, CRP and PTX3 values were found to be significantly increased in the appendicitis group ( $\mathrm{p}<0.00 \mathrm{I}$ ). PTX3 has the highest diagnostic value $(A \cup C=0.828)$, specificity $(88 \%)$ and positive predictive value $(90 \%)$ in the appendicitis group. WBC values did not show a significant correlation with the time periods $(p=0.999)$. The mean CRP level of the appendicitis group in $24-48$ hours was found to be higher than in $0-24$ hours, but this was marginally significant $(p=0.068)$. On the other hand, PTX3 value was significantly correlated with the time periods $(p<0.05)$.
\end{abstract}

CONCLUSION: This study showed that PTX3 is a valuable inflammatory biomarker in the diagnosis of acute appendicitis and also documented that PTX3 is useful for predicting the progression of the disease.

Keywords: Abdominal pain; appendicitis; children; pentraxin 3.

\section{INTRODUCTION}

Abdominal pain is a common entity in the pediatric population. Although right lower quadrant (RLQ) pain principally brings to mind appendicitis worldwide, RLQ usually remains a diagnostic dilemma for the clinicians in children because many non-surgical conditions also cause RLQ pain and clinically mimic appendicitis. ${ }^{[l]}$ Although laboratory tests showing inflammation, and radiological studies are helpful diagnostic tools, the results sometimes do not support the diagnosis in the initial phase of appendicitis and may cause a delay in the treatment, which is associated with increased risk of complicated appendicitis. In this respect, new diagnostic tools are needed to differentiate the early phase of appendicitis from nonspecific abdominal pain.

Appendicitis is a suppurative inflammatory process of the vermiform appendix. C-reactive protein (CRP) is an inflammatory biomarker, which has been widely used in the diagnosis of appendicitis in daily practice. ${ }^{[2]}$ CRP reaches its peak level within the first 48 hours of the inflammatory process. ${ }^{[3-5]}$ For this reason, negative CRP values obtained in the early

Cite this article as: Duman L, Cesur Ö, Kumbul Doğuç D, Çelik S, Karaibrahimoğlu A, Savaş MÇ. Diagnostic value of serum pentraxin 3 level in children with acute appendicitis. Ulus Travma Acil Cerrahi Derg 2020;26:699-704.

Address for correspondence: Levent Duman, M.D.

Süleyman Demirel Üniversitesi Tıp Fakültesi, Çocuk Cerrahisi Anabilim Dalı, 32260 Isparta, Turkey

Tel: +90246 - 2119249 E-mail: leduman@gmail.com

Ulus Travma Acil Cerrahi Derg 2020;26(5):699-704 DOI: 10.14744/tjtes.2020.23258 Submitted: 19.08.2019 Accepted: 05.02.2020 Online: 09.09.2020

Copyright 2020 Turkish Association of Trauma and Emergency Surgery 
phase of appendicitis may be misleading. Recently, pentraxin 3 (PTX3) has been started to use as a diagnostic tool in inflammatory conditions. PTX3 is a protein from the same family with CRP, but its blood levels increase more rapidly than CRP during acute inflammation. ${ }^{[6,7]}$ In this respect, we hypothesized that PTX3 might be a potential diagnostic tool for early diagnosis of acute appendicitis. We designed a prospective, controlled clinical trial to test the diagnostic value of PTX3 for acute appendicitis in children and to investigate whether there is a relationship between the progression of the disease and PTX3 level.

\section{MATERIALS AND METHODS}

\section{Ethical Approval}

Permission from the institutional review board was obtained before this prospective clinical trial (IRB approval number: 04.07.2018-127). Informed consent was obtained from one of the parents of each patient before the study.

\section{Study Groups}

This study was performed between July 2018 and April 2019 on 95 children (87 consecutive children who presented to the emergency service with RLQ pain suggesting acute appendicitis, and eight healthy children). On admission, all children were examined by an experienced pediatric surgeon. Demographic data (age and sex), medical history, the time from the onset of symptoms to blood sampling, WBC counts and CRP levels at admission, operative and pathological findings of the patients were noted. A total of 25 children who documented complicated appendicitis $(n=I I)$, negative appendectomy $(n=I)$, RLQ pain lasting more than 48 hours $(n=5)$, Meckel's diverticulitis $(n=1)$, mesenteric lymphadenitis $(n=I), R L Q$ pain with acute tonsillitis $(n=2)$ and urinary tract infection $(n=l)$, and a history of antibiotic usage in the 10 days preceding admission $(n=3)$ were excluded from this study. The remaining 70 children were divided into three groups as follows: I) Appendicitis group $(n=37)$ included patients undergoing appendectomy in whom the diagnosis was confirmed by histopathological examination, 2) Abdominal pain group $(n=25)$ included other patients who were observed for suspected acute appendicitis without any medication and discharged after abdominal pain completely resolved, 3 ) Control group $(n=8)$ included only healthy children. Patients with appendicitis were further divided into two subgroups according to the duration of symptoms as RLQ pain lasting less than $24 \mathrm{~h}(\mathrm{n}=28)$ and between 24-48 h $(n=9)$.

\section{Collection of Blood Samples}

Blood samples were obtained from the patients for analysis of the serum PTX3 at the same time with WBC and CRP samples. They were centrifugated for 10 minutes at $3000 \mathrm{rpm}$. Plasma was separated and stored at $-80{ }^{\circ} \mathrm{C}$ until used for biochemical assay.

\section{Determination of PTX3 Levels}

PTX3 levels were measured using an enzyme-linked immunosorbent assay commercial kit (Human PTX3 Elisa Kit, Shanghai YL Biotech Co., Ltd., Shanghai, China) according to recommendations of the manufacturer. The absorbance of the samples was measured using a microplate reader (Rayto RT-6000 Microplate Reader, China) at a $450 \mathrm{~nm}$ wavelength. A standard chart was prepared using absorbance values obtained against standard concentrations. Results were calculated using this chart and were expressed as nanograms per milliliters $(\mathrm{ng} / \mathrm{mL})$.

\section{Statistical Analysis}

Data were analyzed using SPSS software for Windows (release 20.0; SPSS Inc., Chicago, IL, USA). Numerical data were expressed as mean \pm standard deviation of the mean and categorical data were expressed as frequencies (percentages). Statistical comparisons among the groups were made by Kruskal-Wallis and Mann-Whitney $U$ tests for numerical variables due to the continuous variables that were not distributed normally, and the Chi-square test for categorical variables. The optimum cut-off value, sensitivity, specificity and predictive values of the studied biomarkers were determined by the receiver operation characteristic (ROC) analysis with $95 \%$ $\mathrm{Cl}$. The area under the ROC curve (AUC) of 0.5 to 0.7 is considered low, 0.7 to 0.8 is considered acceptable, 0.8 to 0.9 is considered excellent, and more than 0.9 is considered outstanding diagnostic value. ${ }^{[8]} \mathrm{P}$ values less than 0.05 were considered to be statistically significant.

\section{RESULTS}

The demographic data, the time from the onset of abdominal pain to blood sampling, and the mean WBC, CRP and PTX3 values of the study groups are given in Table I. There was no statistically significance between the groups concerning age, sex, and time $(p>0.05)$. Distribution of the biomarker values among the groups were also shown in Fig. I. The mean WBC, CRP and PTX3 values were found to be significantly increased in the appendicitis group when compared with the others $(p<0.00 \mathrm{I})$. The mean WBC, CRP and PTX3 values by the time periods (0-24 and 24-48 h) in the appendicitis group are shown in Table 2. Although CRP and PTX3 values were found to be increased by the time periods, this increase was significant only for PTX3 $(p<0.05)$. The predictive power of the studied biomarkers in the diagnosis of acute appendicitis and ROC curve analyses are given in Table 3 and Fig. 2, respectively. PTX3 has the highest diagnostic value $(A \cup C=0.828)$ in children with acute appendicitis.

\section{DISCUSSION}

Appendicitis is the most common surgical abdominal emergency in childhood. Although clinical, laboratory and radiological features of appendicitis have been well documented, its definitive diagnosis may be elusive in children at the time 
Table I. The mean values of the demographic data, time periods, and inflammatory biomarkers

\begin{tabular}{|c|c|c|c|c|}
\hline & Group I $(n=37)$ & Group $2(n=25)$ & Group $3(n=8)$ & $\mathbf{p}$ \\
\hline Age (years) & $12.14 \pm 3.47$ & $11.68 \pm 3.24$ & $8.88 \pm 3.52$ & 0.119 \\
\hline Sex (male/female), n (\%) & $26(70 \%) / I I(30 \%)$ & $15(60 \%) / 10(40 \%)$ & $5(63 \%) / 3(37 \%)$ & 0.479 \\
\hline Time $(h)$ & $15.86 \pm 9.19$ & $12.32 \pm 9.68$ & NA & 0.068 \\
\hline White blood cell (cell $/ \mu \mathrm{L})$ & $16108 \pm 3684^{*}$ & $12004 \pm 6387$ & $7125 \pm 1044$ & $<0.001$ \\
\hline C-reactive protein (mg/L) & $31.64 \pm 38.50^{*}$ & $7.65 \pm 15.98$ & $0.57 \pm 0.59$ & $<0.001$ \\
\hline Pentraxin 3 (ng/mL) & $14.35 \pm 7.32^{*}$ & $6.88 \pm 2.93$ & $4.33 \pm 0.34$ & $<0.001$ \\
\hline
\end{tabular}

of initial assessment. ${ }^{[1]}$ Misdiagnosis may lead to complications on the one hand or an unnecessary surgery on the other. Both consequences are not desired in the management of appendicitis. Thus, many studies, like the present study, have focused on new diagnostic tools that can differentiate acute appendicitis from other non-surgical causes of abdominal pain.

Children with appendicitis more commonly present with perforation than adults. ${ }^{[1]}$ A previous study demonstrated that the prevalence of perforation is $7 \%$ within the first 24 hours after the onset of symptoms, $38 \%$ when symptoms are present less than 48 hours, and $98 \%$ when symptoms are present for more than 48 hours. ${ }^{[9]}$ This finding clearly shows that increased duration of symptoms is associated with an increased risk of perforation. Especially the first 24-48 hours are critical to a definitive diagnosis and treatment. The concentration of inflammatory markers, such as CRP, increases with the duration and the severity of the inflammatory process. ${ }^{[10]}$ Thus, patients with longer duration of symptoms are expected to have higher values. However, the duration of symptoms has been ignored in the vast majority of biomarker studies in appendicitis. The measurements at different times produce different values. In this respect, significant results can be achieved with higher values obtained from patients with a longer duration of symptoms, while lower values obtained in patients presenting earlier may result in insignificant results. Therefore, the duration of symptoms was considered in the
Table 2. The mean inflammatory biomarker values of the appendicitis group by time periods

\begin{tabular}{lccc}
\hline & $\mathbf{0 - 2 4} \mathbf{~ h}$ & $\mathbf{2 4 - 4 8 ~ h}$ & $\mathbf{p}$ \\
\hline White blood cell $($ cell $/ \mu \mathrm{L})$ & $16221 \pm 4049$ & $15755 \pm 2356$ & 0.999 \\
C-reactive protein $(\mathrm{mg} / \mathrm{L})$ & $20.94 \pm 22.72$ & $64.92 \pm 57.30$ & 0.068 \\
Pentraxin 3 $(\mathrm{ng} / \mathrm{mL})$ & $12.73 \pm 6.52$ & $19.40 \pm 7.74 *$ & 0.020 \\
\hline *Significant as $p<0.05$. & & &
\end{tabular}

present study to obtain more accurate results, and to investigate the relationship between the progression of the disease and the level of studied markers.

Appendicitis causes a systemic inflammatory response, so inflammatory biomarkers, such as WBC and CRP, have long been used in the diagnosis. ${ }^{\left[{ }^{\prime \prime}\right]}$ Although the increase in WBC is generally accepted as an early sign of appendix inflammation, elevated or normal values of WBC are not reliable to diagnose or exclude appendicitis. Because patients with many other conditions, such as gastroenteritis, mesenteric lymphadenitis and infections, may have an elevated WBC. ${ }^{[2]}$ Moreover, it is not surprising that children with appendicitis may have WBC within normal limits. ${ }^{[12]}$ The previous studies showed that the sensitivity of WBC in the diagnosis of acute appendicitis ranges between $62 \%$ and $97 \%$ and the specificity ranges between $53 \%$ and $80 \% .^{[2,11-14]}$ WBC showed an ac-
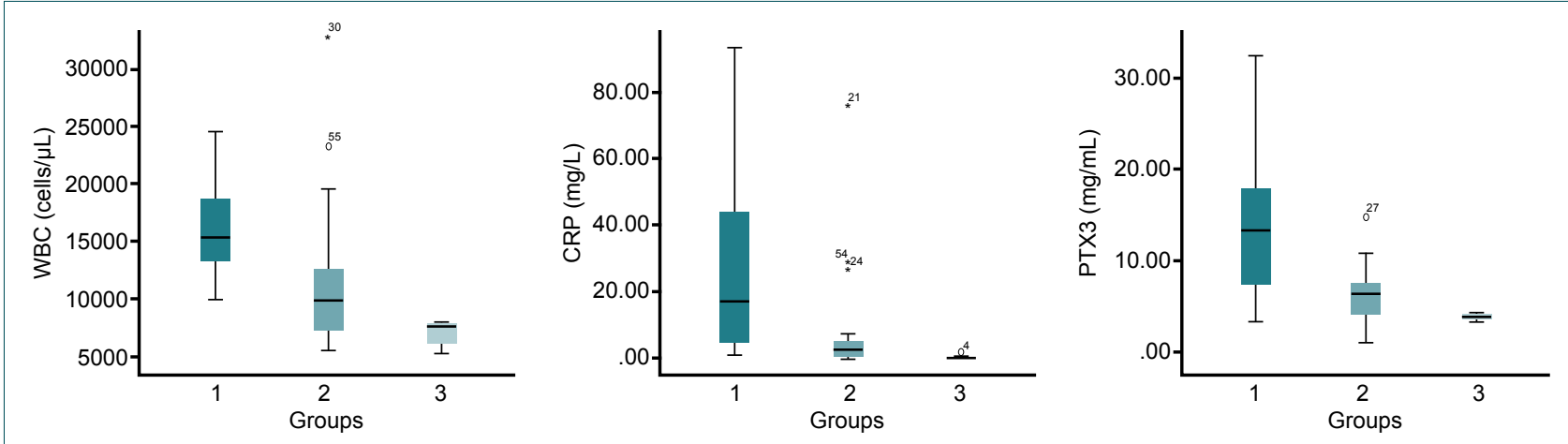

Figure 1. Distribution of the WBC, CRP and PTX3 values among the groups. WBC: White blood cell; CRP: C-reactive protein; PTX3: Pentraxin 3. 
Table 3. Predictive power of the WBC, CRP and PTX3 in the diagnosis of acute appendicitis

\begin{tabular}{lcccccc}
\hline & Cut-off value & AUC & Sensitivity & Specificity & PPV & NPV \\
\hline White blood cell & 12750 & $0.778^{*}$ & 83.78 & 76.00 & 83.78 & 76.00 \\
& & & $(67.99-93.8 I)$ & $(54.87-90.64)$ & $(71.72-91.33)$ & $(59.58-87.19)$ \\
C-reactive protein & 5.65 & $0.809^{*}$ & 72.97 & 84.00 & 87.10 & 67.74 \\
& & & $(55.88-86.21)$ & $(63.92-95.46)$ & $(72.91-94.42)$ & $(54.62-78.56)$ \\
Pentraxin 3 & 9.31 & $0.828^{*}$ & 72.97 & 88.00 & 90.00 & 68.75 \\
& & & $(55.88-86.21)$ & $(68.78-97.45)$ & $(75.36-96.36)$ & $(55.96-79.21)$ \\
\hline "Significant as $p<0.001$. Values in parentheses are 95\% confidence intervals. AUC: Area under ROC curve; PPV: Positive predictive value; NPV: Negative predictive value.
\end{tabular}

ceptable diagnostic value (AUC=0.778) for acute appendicitis with $83.78 \%$ sensitivity and $76 \%$ specificity in the present study. Our results also supported the previous meta-analyses suggesting that WBC is more sensitive but less specific than CRP in the early stage of acute appendicitis. ${ }^{[2,15]}$ Another finding of our study was that mean WBC values did not show a significant correlation with the time periods $(p=0.999)$. This finding suggests that WBC is not a useful parameter to show the severity of appendiceal inflammation; in other words, the progression of the disease.

PTXs are acute-phase proteins that play major roles in the humoral arm of innate immunity and serve as markers of inflammation. ${ }^{[16]}$ Based on the primary structure, they are divided into two subfamilies as short and long PTXs. CRP is a classic short PTX that is produced by hepatocytes in response to cytokine stimulation triggered by a bacterial infection, trauma, tissue necrosis, and most forms of inflammation. ${ }^{[7]}$ The results from previous studies showed that CRP is not an ideal diagnostic tool for ruling out or determination of acute appendicitis, and has more diagnostic accuracy in detecting complicated appendicitis. ${ }^{[14,17-19]}$ Although the sensitivity of CRP in the

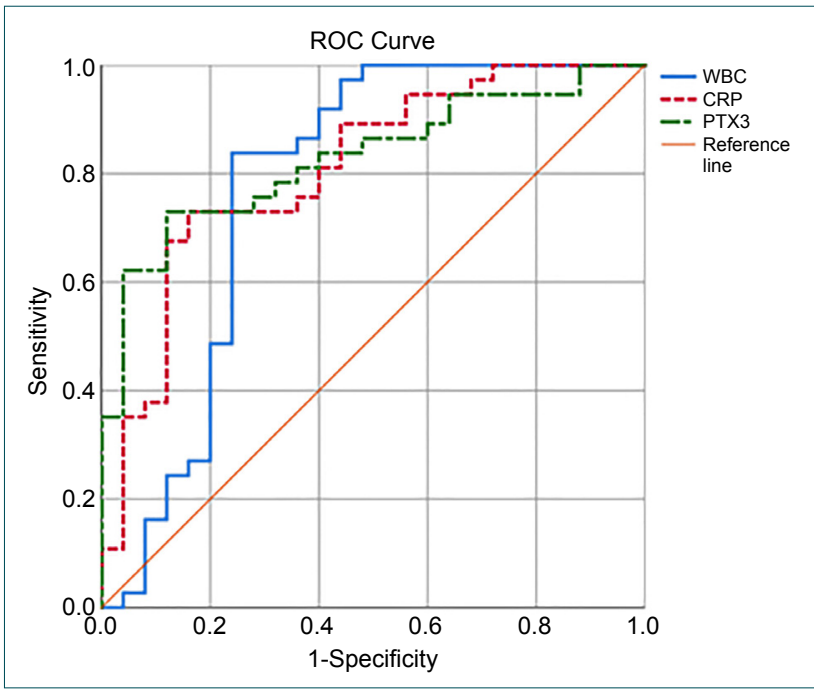

Figure 2. ROC curve analyses of the diagnostic value of serum WBC, CRP and PTX3 for acute appendicitis in children. WBC: White blood cell; CRP: C-reactive protein; PTX3: Pentraxin 3. diagnosis of acute appendicitis ranged between $35 \%$ and $86 \%$ and the specificity ranges between $57 \%$ and $93 \%$ in the literature, ${ }^{[11,12,19-21]}$ a CRP cut-off value of 5.65 produced $72.97 \%$ sensitivity, $84 \%$ specificity, and an excellent diagnostic value $(A \cup C=0.809)$ in our study. Our results addressed that CRP is still a helpful inflammatory biomarker in the diagnosis of acute appendicitis in children. Some studies suggested that its level increases in appendicitis, which is related to the severity of appendiceal inflammation. ${ }^{[22,23]}$ On the other hand, the mean CRP levels in 24-48 hours of appendicitis group were found to be higher in our study, but this was marginally significant $(p=0.068)$. This result may be interpreted as CRP has a low or moderate value in showing the progression of the disease.

PTX3 is the prototype of long PTXs that is produced at local sites where the primary inflammation occurs. ${ }^{[7]}$ Its blood levels are low in normal conditions but increase rapidly during acute inflammation. ${ }^{[24,25]}$ Production of PTX3 is mediated by early proinflammatory cytokines, such as interleukin (IL)-I and tumor necrosis factor- $\alpha$ in endothelial cells and mononuclear phagocytes. However, a previous study reported that PTX3 is stored in a ready-made form in specific granules of neutrophils, and is rapidly released within minutes to sites where tissue damage or microbial stimulation are occurring. [26] In contrast, the production of CRP has a slower time course than PTX3 because it is mediated by the secondary cytokine IL-6 and is produced only in the liver. ${ }^{[7,16]}$ Therefore, PTX3 is expected to increase earlier than CRP in the course of acute inflammation. In this respect, PTX3 is a potential early diagnostic marker of inflammation and tissue damage. To our knowledge, only two clinical studies examined the role of PTX3 in the diagnosis of acute appendicitis to date. ${ }^{[14,27]}$ The first preliminary study in adults propounded that PTX3 levels were significantly higher in patients with acute appendicitis (mean $3.28 \mathrm{ng} / \mathrm{ml}$ ) than non-specific abdominal pain group (mean $1.3 \mathrm{I} \mathrm{ng} / \mathrm{ml}$ ), and PTX3 showed an acceptable diagnostic value $(A \cup C=0.739)$. However, this study obtained confusing results with three different cut-off values of PTX3. ${ }^{[27]}$ The first study in children achieved very ambitious results in which a PTX3 cut-off value 5.6 produced $91.8 \%$ sensitivity, $90.7 \%$ specificity, and an outstanding diagnostic value (AUC=0.979), and concluded that a high PTX3 level is a strong indicator of 
appendicitis. $^{[14]}$ In our study, a PTX3 cut-off value of 9.31 produced $72.97 \%$ sensitivity and $88 \%$ specificity, and an excellent diagnostic value (AUC=0.828). However, the present study is novel in two aspects. First, the above-mentioned studies did not investigate the time from the onset of symptoms to blood sampling (disease progression bias). Second, PTX3 value was significantly correlated with the time periods $(p<0.05)$. This result suggests that $\mathrm{PTX} 3$ is a useful biomarker in showing progression of the disease.

Many potential biomarkers, such as procalcitonin, bilirubin, mean platelet volume, D Dimer and calprotectin, have been studied in the diagnosis of appendicitis. ${ }^{[2,28-31]}$ Although some studies have found significant results with various diagnostic value, their role in the diagnosis still contains some controversies, and most have not still been used in daily practice. Although studies about the diagnostic role of PTX3 in appendicitis are limited, the promising results of our study suggest that PTX3 may find a place in daily practice in the future due to its high diagnostic value.

\section{Conclusion}

The present study showed that PTX3 is a valuable inflammatory biomarker in the diagnosis of acute appendicitis and may also be useful in predicting the progression of the disease. However, the results of the test should be interpreted carefully in conjunction with a medical history, physical examination, and radiological studies, and further prospective clinical studies, including a larger number of patients, are needed to achieve more accurate results.

Ethics Committee Approval: Approved by the local ethics committee.

\section{Peer-review: Internally peer-reviewed.}

Authorship Contributions: Concept: L.D.; Design: L.D.; Supervision: M.Ç.S.; Materials: L.D., Ö.C.; Data: L.D., Ö.C., D.K.D., S.Ç., M.Ç.S.; Analysis: A.K.; Literature search: L.D., Ö.C.; Writing: L.D., M.Ç.S.; Critical revision: L.D., M.Ç.S.

\section{Conflict of Interest: None declared.}

Financial Disclosure: The authors declared that this study has received no financial support.

\section{REFERENCES}

1. Dunn JCY. Appendicitis. In: Pediatric Surgery. Coran AG, Caldamone A, Adzick NS, Krummel TN, Laberge JM, Shamberger R, editors. 7th edition. Philadelphia: Elsevier Saunders; 2012.p.1255-63. [CrossRef]

2. Yu CW, Juan LI, Wu MH, Shen CJ, Wu JY, Lee CC. Systematic review and meta-analysis of the diagnostic accuracy of procalcitonin, C-reactive protein and white blood cell count for suspected acute appendicitis. British J Surg 2013;100:322-9. [CrossRef]

3. Pepys MB. C-reactive protein fifty years on. Lancet 1981;1:653-7.

4. Ledue TB, Rifai N. Preanalytic and analytic sources of variations in C-reactive protein measurement: implications for cardiovascular disease risk assessment. Clin Chem 2003;49:1258-71. [CrossRef]
5. Pepys MB, Hirschfield GM. C-reactive protein: a critical update. J Clin Invest 2003;111:1805-12. [CrossRef]

6. Peri G, Introna M, Corradi D, Iacuitti G, Signorini S, Avanzini F, et al. PTX3, A prototypical long pentraxin, is an early indicator of acute myocardial infarction in humans. Circulation 2000;102:636-41. [CrossRef]

7. Daigo K, Mantovani A, Bottazzi B. The yin-yang of long pentraxin PTX3 in inflammation and immunity. Immunol Lett 2014;161:38-43.

8. Hosmer DW, Lemeshow S. Area under the ROC curve. In: Applied Logistic Regression. Hosmer DW, Lemeshow S, editors. 2nd edition. New York, USA: John Wiley and Sons; 2000.p.160-4. [CrossRef]

9. Rothrock SG, Pagane J. Acute appendicitis in children: emergency department diagnosis and management. Ann Emerg Med 2000;36:39-51.

10. Sproston NR, Ashworth JJ. Role of C-Reactive Protein at Sites of Inflammation and Infection. Front Immunol 2018;9:754. [CrossRef]

11. Buyukbese Sarsu S, Sarac F. Diagnostic value of white blood cell and C-reactive protein in pediatric appendicitis. Biomed Res Int 2016;2016:6508619. [CrossRef]

12. Grönroos JM. Do normal leucocyte count and C-reactive protein value exclude acute appendicitis in children? Acta Paediatr 2001;90:649-51.

13. Shafi SM, Afsheen M, Reshi FA. Total leucocyte count, C-reactive protein and neutrophil count: diagnostic aid in acute appendicitis. Saudi J Gastroenterol 2009;15:117-20. [CrossRef]

14. Oztan MO, Aksoy Gokmen A, Ozdemir T, Müderris T, Kaya S, Koyluoglu G. Pentraxin-3: A strong novel biochemical marker for appendicitis in children. Am J Emerg Med 2019;37:1912-6. [CrossRef]

15. Andersson RE. Meta-analysis of the clinical and laboratory diagnosis of appendicitis. Br J Surg 2004;91:28-37. [CrossRef]

16. Magrini E, Mantovani A, Garlanda C. The Dual Complexity of PTX3 in Health and Disease: A Balancing Act?. Trends Mol Med 2016;22:497-510. [CrossRef]

17. Jangjoo A, Varasteh AR, Bahar MM, Meibodi NT, Aliakbarian M, Hoseininejad $\mathrm{M}$, et al. Is $\mathrm{C}$-reactive protein helpful for early diagnosis of acute appendicitis? Acta Chir Belg 2011;111:219-22. [CrossRef]

18. Amalesh T, Shankar M, Shankar R. CRP in acute appendicitis--is it a necessary investigation?. Int J Surg 2004;2:88-9. [CrossRef]

19. Sack U, Biereder B, Elouahidi T, Bauer K, Keller T, Tröbs RB. Diagnostic value of blood inflammatory markers for detection of acute appendicitis in children. BMC Surg 2006;6:15. [CrossRef]

20. Benito J, Acedo Y, Medrano L, Barcena E, Garay RP, Arri EA. Usefulness of new and traditional serum biomarkers in children with suspected appendicitis. Am J Emerg Med 2016;34:871-6. [CrossRef]

21. Asfar S, Safar H, Khoursheed M, Dashti H, al-Bader A. Would measurement of $\mathrm{C}$-reactive protein reduce the rate of negative exploration for acute appendicitis?. J R Coll Surg Edinb 2000;45:21-4.

22. Shakhatreh HS. The accuracy of $\mathrm{C}$-reactive protein in the diagnosis of acute appendicitis compared with that of clinical diagnosis. Med Arh 2000;54:109-10.

23. Gavela T, Cabeza B, Serrano A, Casado-Flores J. C-reactive protein and procalcitonin are predictors of the severity of acute appendicitis in children. Pediatr Emerg Care 2012;28:416-9. [CrossRef]

24. Yamasaki K, Kurimura M, Kasai T, Sagara M, Kodama T, Inoue K. Determination of physiological plasma pentraxin 3 (PTX3) levels in healthy populations. Clin Chem Lab Med 2009;47:471-7. [CrossRef]

25. Inforzato A, Jaillon S, Moalli F, Barbati E, Bonavita E, Bottazzi B, et al. The long pentraxin PTX3 at the crossroads between innate immunity and tissue remodelling. Tissue Antigens 2011;77:271-82. [CrossRef]

26. Jaillon S, Peri G, Delneste Y, Frémaux I, Doni A, Moalli F, et al. The humoral pattern recognition receptor PTX3 is stored in neutrophil granules 
and localizes in extracellular traps. J Exp Med 2007;204:793-804.

27. Aygun A, Katipoglu B, İmamoglu M, Demir S, Yadigaroglu M, Tatli O, et al. Diagnostic Value of Plasma Pentraxin-3 in Acute Appendicitis. J Invest Surg 2019;32:143-8. [CrossRef]

28. Motie MR, Nik MM, Gharaee M. Evaluation of the diagnostic value of serum level of total bilirubin in patients with suspected acute appendicitis. Electron Physician 2017;9:4048-54. [CrossRef]

29. Fan Z, Zhang Y, Pan J, Wang S. Acute Appendicitis and Mean Plate- let Volume: A Systemic Review and Meta-analysis. Ann Clin Lab Sci 2017;47:768-72.

30. Cayrol J, Miguez MC, Guerrero G, Tomatis C, Simal I, Marañón R. Diagnostic accuracy and prognostic utility of D Dimer in acute appendicitis in children. Eur J Pediatr 2016;175:313-20. [CrossRef]

31. Ambe PC, Gödde D, Bönicke L, Papadakis M, Störkel S, Zirngibl H. Calprotectin could be a potential biomarker for acute appendicitis. J Transl Med 2016;14:107. [CrossRef]

\section{ORIJINAL ÇALIŞMA - ÖZET}

\section{Akut apandisitli çocuklarda serum pentraksin 3 düzeyinin tanısal değeri \\ Dr. Levent Duman, ${ }^{1}$ Dr. Özkan Cesur, ${ }^{1}$ Dr. Duygu Kumbul Doğuç, ${ }^{2}$ Dr. Seda Çelik, ${ }^{2}$ Dr. Adnan Karaibrahimoğlu, ${ }^{3}$ Dr. Mustafa Çağrı Savaş ${ }^{1}$}

'Süleyman Demirel Üniversitesi Tıp Fakültesi, Çocuk Cerrahisi Anabilim Dalı, Isparta

${ }^{2}$ Süleyman Demirel Üniversitesi Tıp Fakültesi, Biyokimya Anabilim Dalı, Isparta

${ }^{3}$ Süleyman Demirel Üniversitesi Tıp Fakültesi, Biyoistatistik ve Tıbbi Bilişim Anabilim Dalı, Isparta

AMAÇ: Apandisit en sık görülen cerrahi acillerden biridir. Çocuklarda apandisitin erken tanısı önemlidir, çünkü tedavideki herhangi bir gecikme büyük ölçüde komplike apandisite yol açar. Bu çalışmada, akut apandisitli çocuklarda pentraksin 3 (PTK3) düzeyinin tanısal değerini ve hastalığın ilerlemesi ile PTK3 seviyesi arasında bir ilişki olup olmadığııı araştırmayı amaçladık.

GEREÇ VE YÖNTEM: Bu çalışmaya 70 çocuk alındı. Çocuklar 3 gruba ayrıldı: Grup I (apandisit; n=37), grup 2 (karın ağrısı; n=25), grup 3 (kontrol; $n=8$ ). Demografik veriler, tıbbi öykü, semptomların başlangıından kan örneklemesine kadar geçen süre, hastaların ameliyat ve patolojik bulguları kaydedildi ve beyaz küre (BK), C-reaktif protein (CRP) ve PTK3 değerleri ölçüldü.

BULGULAR: Apandisit grubunda ortalama BK, CRP ve PTK3 değerleri anlamlı olarak yüksek bulundu $(p<0.00 I)$. Apandisit grubunda PTK3 en yüksek tanı değerine (AUC=0.828), özgüllüğe (\%88) ve pozitif öngörü değerine (\%90) sahipti. BK değerleri zaman dilimleri ile anlamlı bir korelasyon göstermedi $(p=0.999)$. Apandisit grubunda $24-48$ saatteki ortalama CRP değeri, $0-24$ saattekinden daha yüksek bulundu, ancak bu sınırda anlamlı idi $(p=0.068)$. Diğer taraftan, PTK3 değeri zaman dilimleri ile anlamlı olarak korele idi $(p<0.05)$.

TARTIŞMA: Bu çalışma, PTK3'ün akut apandisit tanısında değerli bir enflamatuvar biyobelirteç olduğunu göstermiş ve ayrıca hastalığın ilerlemesini tahmin etmek için de yararlı olduğunu belgelemiştir.

Anahtar sözcükler: Apandisit; çocuklar; karın ağrısı; pentraksin 3.

Ulus Travma Acil Cerrahi Derg 2020;26(5):699-704 doi: 10.14744/tjtes.2020.23258 